\title{
Giorgio La Piana and the Religious Crisis in Italy at the Beginning of the Twentieth Century
}

Daniela Saresella

University of Milan

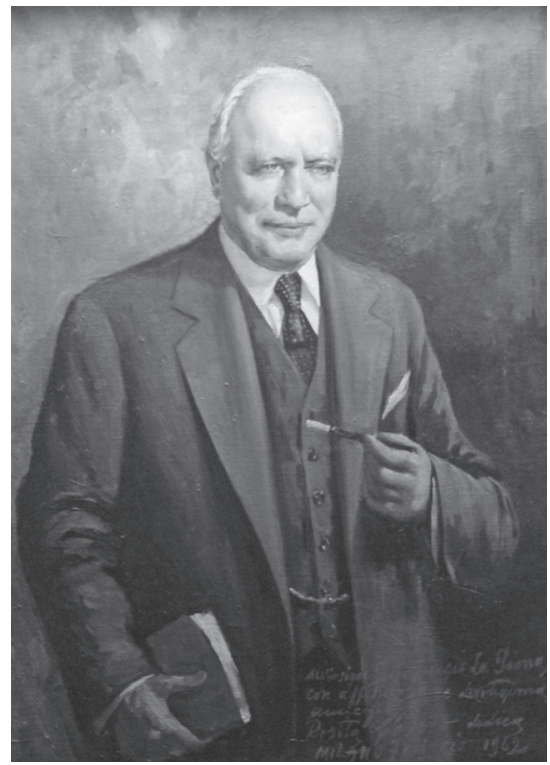

Figure 1

One of the most notable Catholic personalities in Modernism, the well-known current of thought headed in Italy by Ernesto Buonaiuti, Giorgio La Piana deserves more thorough consideration. Like many priests and laymen, La Piana owed an intellectual debt to Buonaiuti, with whom he shared a common interest in the early

${ }^{1}$ Rosita Casero, George La Piana, 1962, oil on canvas, Cambridge, MA, Harvard University Portrait Collection, Harvard Divinity School, photograph by Jonathan Beasley.

HTR 110:1 (2017) 75-99 
history of the church as well as in medieval theologian and mystic Gioacchino da Fiore, who prophesied the advent of a spiritual church. They also enjoyed a longlasting friendship. What distinguished La Piana among his generation of scholars, who gave rise to the so-called "Modernist crisis," was his choice to migrate to the United States, where he acted as a bridge between American and Italian culture. Notably, he translated George Foot Moore's works into Italian and Buonaiuti's essays into English for publication in the Harvard Theological Review. La Piana became a point of reference for some Italian scholars of the history of the church and religions who had studied under Buonaiuti (such as Alberto Pincherle, Mario Niccoli, Ambrogio Donini, Giorgio Della Vida, and Arturo Carlo Jemolo) and who had considerable problems with the fascist regime. It was often thanks to La Piana that they managed to make contact with the intellectual and academic worlds in the United States.

\section{Between Sicily and America}

Giorgio La Piana was born in Piana degli Albanesi (near Palermo) on 28 February $1878^{2}$ into a well-off family of ancient Albanese origins. The third child of a large family, like his brothers he was sent to study at the seminary of Monreale at the age of $8 .^{3}$ His education was in many respects representative of the learning experience of a whole generation of seminarians who would be involved in the Modernist crisis movement-an intellectual catholic movement that emerged in Europe in the early twentieth century and that intended to foster a critical approach to the teachings of the Roman Catholic Church, which they considered to be too closed towards any secular influence. Indeed, nineteenth-century seminaries in Italy intended to produce a clergy educated according to the canons of the great scholastics. In particular, the encyclical Aeterni Patris set aside the philosophy of Saint Augustine and all those theologians who did not take as their guide the thought of Aquinas, although Augustine had provided considerable inspiration and challenges to Christian thought. Meanwhile, a distinct tendency towards pluralism of thought was taking root in lay culture. ${ }^{4}$

In the second half of the eighteenth century, the Monreale seminary made important contributions to the field of philosophy: the leading figure in the seminary had been Vincenzo Miceli, who aimed to fight skepticism and rationalism by demonstrating the harmony between philosophy and theology. Miceli founded the "School of Monreale," which was culturally relevant until halfway through the eighteenth century, when, following the conservative turn of the Roman Church,

${ }^{2}$ La Piana's certificate of baptism can be found in the Archivio Storico Diocesano, in Sezione 2, Serie 3-6b, numero 37, busta 269, Monreale Archbishopric's Archives, Fondo Governo Ordinario.

3 “Childhood," Giorgio La Piana Papers, bMS 104, Andover-Harvard Theological Library, Harvard Divinity School.

${ }^{4}$ Maurilio Guasco, Fermenti nei seminari del primo Novecento (Bologna: Dehoniane, 1971) 12-18. 
it abandoned its most radical stances in keeping with the conservative atmosphere that characterized the turn of the century. ${ }^{5}$ Writing about the seminary that trained him, La Piana emphasized the very atmosphere of renewal characterizing the early years of the Monreale school:

Monreale had also had a tradition of philosophical studies which had no connection with scholasticism such as it was taught in Jesuit colleges, a mixture of medieval method with the new systematization attempted by post-reformation thinkers, especially of the French school. While, along philosophical lines, the door had opened to all kinds of vagaries and attempts to rationalize an emotional motive, in theology, on the contrary, Thomism kept its Thomistic tradition unchanged - nay strengthened it all the more as a reaction against the novelties introduced by the various schools. ${ }^{6}$

La Piana makes clear that the Monreale seminary, which in the past had distinguished itself for the openness of its philosophical tradition, went back to the Thomist tradition in the wake of closure that characterized the church after the French Revolution out of fear of rationalism and anti-Christian ideas. However, while acknowledging the innovative function of the school in its heyday, La Piana was not blind to the oppressive and conservative atmosphere that had characterized his seminary years at the end of the nineteenth century. For example, in 1892 two important ecclesiastical figures in the diocese, don Giuseppe Fiorenza and don Gaetano Millunzi, printed an essay entitled Dieci quesiti riguardanti $i$ seminari italiani nelle attuali condizioni (ten questions regarding Italian seminaries in the present context), which suggested strict supervision of textbooks and, above all, opposed seminarists obtaining diplomas in state schools. ${ }^{7}$ Thus, when La Piana arrived at the seminary, "Aquino-thought dominated."

\footnotetext{
${ }^{5}$ Francesco Conigliaro, Un secolo di teologia in Sicilia (San Cataldo: Centro Studi Cammarrata, 1998) 22-37. See also Gaetano Millunzi, Storia del Seminario arcivescovile di Monreale (Siena: San Bernardino, 1895).

6 "Education and vocation, including Monreale period," Giorgio La Piana Papers, bMS 104, Andover-Harvard Theological Library, Harvard Divinity School.

${ }^{7}$ Dieci quesiti riguardanti i seminari italiani nelle attuali condizioni. Studio dei reverendissimi D. Giuseppe Fiorenza D. Gaetano Millunzi, canonici e parroci della Metropolitana di Monreale (Siena: 1892).

8 "Education and vocation, including Monreale period," Giorgio La Piana Papers, bMS 104, Andover-Harvard Theological Library, Harvard Divinity School. On D'Acquisto, see: Francesco Lorico, Vita di Benedetto D'Acquisto (Palermo: 1899); Salvatore Caramella, "La filosofia di Benedetto D'Acquisto," in Atti dell'Accademia di Scienze Lettere e Arti di Palermo 27 (1966-1967) 38-51; Francesco Conigliaro, Un secolo di teologia in Sicilia. Cultura ecclesiastica e teologi siciliani tra $i$ due Concili Vaticani (San Cataldo: Centro Studi Cammarata, 1998) 145-50. In 1885, the "Accademia Monrealese di S. Tommaso d'Aquino" was founded in Monreale as was the Thomist journal La Favilla in 1890, which was published up to 1894.
} 
In March 1893, La Piana received his clerical tonsure and, in June 1897, was ordained to the minor orders. At the age of 18, he began his studies at the Theological School of Monreale: the curriculum involved concentration on three branches of Christian theology: dogmatic theology, moral theology, and canon law. Dogmatic Theology consisted of analyzing questions relating to Thomas Aquinas' Summa Theologica. Moral Theology was based on the theories of Alfonso de Liguori. Canon Law was based on the Jus Canonicum adopted by the Roman Curia. La Piana observed critically: "The most important thing to notice in that school was the complete lack of historical subjects in the program. There was no idea of Ecclesiastical history, and when I asked why, the only answer we could get was that it was a temporary deficiency to be remedied very soon." The young man's lack of satisfaction with what he considered the inadequate program of studies was clear: "I had a special interest in historical studies, extending from the Medieval period to modern times. The events which accompanied the Risorgimento in Italy and its achievement of political unity were the subject of extensive research reaching different conclusions." Since the interpretation of these historical events in Catholic circles was wholly negative, "they were representative of atheist, irreligious doctrines and practices" and "it can be understood why the seminar's Director of Studies hesitated to introduce the study of history in the Theological School." Most of the students were indifferent to the lack of historical subjects, "but a smaller number of them, who had been proficient as students in the Lyceum, became fully aware of this disastrous and hostile attitude; they tried to fill the gap by reading on their own initiative without the guidance of their conservative older brothers." 9

In those same years, many young people in different parts of the country shared dissatisfaction with the subjects taught in the seminaries. Indeed, the challenges coming from modern culture had led a whole generation to consider the need to adapt Catholic culture to the contemporary world and open up an exchange of opinions. Modernism arose out of this need, but in Sicily it did not spread easily. ${ }^{10}$ Some historians have spoken of a "bland" phenomenon, ${ }^{11}$ even though elements of religious reformism were to be seen in the reflections of some intellectuals, both at a theological and at a socio-political level. ${ }^{12}$ Amongst the Modernists was La Piana, who wrote that, "at the beginning of the new century, the plague of Modernism had spread in many clerical seminaries and usually enlisted the most intelligent and

\footnotetext{
9 "Education and vocation, including Monreale period," Giorgio La Piana Papers, bMS 104, Andover-Harvard Theological Library, Harvard Divinity School.

${ }^{10}$ Pietro Mignosi, Mezzogiorno. Il ragguaglio dell'attività culturale e letteraria dei cattolici in Italia (Palermo: La Tradizione, 1931) 88-91.

${ }^{11}$ Francesco Conigliaro, "Teologia e teologi di Sicilia tra i due Concili Vaticani," in La Chiesa di Sicilia Dal Vaticano I al Vaticano II (ed. Francesca Flores D'Arcais; Caltanissetta-Rome: Sciascia, 1994) 549-641.

${ }^{12}$ Francesco Michele Stabile, La Chiesa nella società siciliana (Caltanissetta-Rome: Sciascia, 1992) 132.
} 
most able members of the scholars"; in particular "in the seminary of Monreale this wave of Modernism found a responsive attitude. We established a kind of Circolo, or club, to discuss religious and social ideas and programs, applying the principles of historical criticism."13

At Monreale, Catholics closer to the principles of tradition did not fail to express their ill-ease and sent concerned letters to the Roman congregation of the seminaries. As a result of these reports, two Apostolic Delegates were sent to inquire. ${ }^{14}$ The apostolic visits to the dioceses ${ }^{15}$ took place mostly between 1904 and 1909 in a climate of great concern in the Roman Curia about the spread of a new and innovative spirit in the Catholic world. Monreale was the first Sicilian diocese to be inspected and the apostolic visit began on 25 July 1904 (and concluded on 30 October of the same year). It was carried out by the Redemptorist Father Ernesto Bresciani, who found dangerous elements of Modernism in the teachings imparted to the seminarists. ${ }^{16}$ La Piana emphasized the fact that Bresciani's "report must have been very black because upon reading it the Roman Congregation suspended all the members of staff of the seminary and sent an Apostolic Administrator to reorganize the school and cut off the head of the Modernist dragon." 17

In 1907, La Piana asked his Ordinary, Lancia di Brolo, the Archbishop of Monreale, for permission to take a year off to study at the Catholic University of Freiburg. ${ }^{18}$ The chance to get away from Italy was important for him because of the atmosphere in the Catholic world. There are many testimonies to the difficulties that Catholic innovators were experiencing in the country: in a 13 November 1906 letter to the Bishop of Cremona, Geremia Bonomelli, Antonio Fogazzaro mentioned a "certain occult spirit of secret inquisition that has turned into spying.

13 "Modernism," Giorgio La Piana Papers, bMS 104, Andover-Harvard Theological Library, Harvard Divinity School.

14 Ibid.

${ }^{15}$ Periodical visits to the dioceses and seminaries of a region, generally carried out by a prelate of the Curia, a Bishop or the head of a seminary, was part of normal administrative practice. However, in the years of the Modernist crisis, the apostolic visitor actually filled the role of Inquisitor, investigating the theological approaches of the seminar's teachers and the educational and disciplinary methods adopted (Maurilio Guasco, La formazione del clero [Milan: Jaca Book, 2002] 59-66).

${ }^{16}$ Massimo Naro, Teologi in ginocchio. Figure di spirituali nella Sicilia contemporanea (Caltanissetta-Rome: Salvatore Sciascia, 2006) 212-13.

17 "Modernism," Giorgio La Piana Papers, bMS 104, Andover-Harvard Theological Library, Harvard Divinity School.

${ }^{18} \mathrm{La}$ Piana received his licentiate in theology in 1900, and on $31 \mathrm{March} 1900$, at the age of 22, he was ordained priest before the high altar of the great Byzantine-Norman cathedral of Monreale. From 1901 to 1904, he taught history in the lower seminary and later began teaching Latin (George $\mathrm{H}$. Williams, "Professor George La Piana (1878-1971). Catholic Modernist at Harvard," HTB 21 [1973] 117-43, at 121). See also the certificate in Archivio Storico Diocesano, Arcidiocesi di Monreale, Fondo Governo Ordinario, Sezione 2, Serie 3-6b, numero 37, busta 269 (Giorgio La Piana). 
People under suspicion are trailed and their houses kept under observation." ${ }^{19}$ And Giovanni Semeria wrote to Tommaso Gallarati Scotti: "I am — we are - spied upon and incredible things are happening. ${ }^{20}$ Giovanni Genocchi observed that those who went to see him at the Università La Sapienza in Roma were reported to the Vatican. ${ }^{21}$

La Piana did not stay long in the Swiss town: he travelled to Berlin, Heidelberg, and Munich. He settled in Geneva, where his friend, Antonino De Stefano, was studying for a $\mathrm{PhD}$ in romance philology. ${ }^{22}$ In Geneva, La Piana carried out studies on the relationship between the state and the church in France, inspired by the debate that had arisen out of the 1905 legislation on the far side of the Alps. In 1908 , he published a long article in the journal Rivista storico-critica delle scienze teologiche. In this essay La Piana concentrated on the complex period preceding the revolution, analyzing the transformation in political-religious ideas and identifying the reforms that were attempted, both those set aside and those that were adopted by the revolution. Many of these projects revealed the atavic "evils of the Church in France" and thus clarified the connection to the French situation at the time. In his study, La Piana dwelt in particular on the various proposals by Fènelon, Fleury, and Saint-Simon, who "busied themselves with the sterile work of filling dangerous cracks, without suspecting that the evil was far deeper and more radical and thus required radical solutions." 23

He obtained his licentiate in letters in 1908, and then returned to Sicily, despite the excommunication of the whole of the Modernist movement, following Pius X's September 1907 encyclical Pascendi Dominici gregis. Alessandro Lualdi, the Cardinal of Palermo, offered him a position as a history teacher at the Collegio San Rocco, a private institute managed directly by the Scolopi, a male religious order independent of the Ordinary of the Diocese. La Piana continued to teach there from 1909 to 1913. In 1910, a further problem arose for all those who had shown sympathy for the church's intentions to carry out reform: Pius X issued

${ }^{19}$ Carlo Marcora, Corrispondenze Fogazzaro-Bonimelli (Milan: Vita e Pensiero, 1968) 92 ("un certo occulto spirito di inquisizione segreta divenuto spionaggio segreto. Si seguono i passi delle persone sospette, si vegliano le case").

${ }^{20}$ Letter from Semeria to Gallarati Scotti, Biblioteca Ambrosiana (Milan), Archivio Gallarati Scotti, Serie III, Carteggi, cart. 1, f. 14 ("Sono e siamo spiati, e stanno accadendo cose incredibili").

${ }^{21}$ Vincenzo Ceresi, Padre Genocchi (Rome: Poliglotta Vaticana, 1934) 299-323. Fogazzaro, Semeria, Gallerati Scotti, and Genocchi were exponents of Italian Modernism.

22 De Stefano (Trapani 1880-Palermo 1964), a friend of La Piana's from his very first years at the Monreale seminary, joined the Modernists and for this reason left the church in 1913. In 1924, he became professor of medieval history at the University of Bologna and then, from 1936, at the University of Palermo.

${ }^{23}$ Giorgio La Piana, "Chiesa e Stato in Francia. Progetti di riforme sui principi del secolo XVIII," Rivista storico-critica delle scienze teologiche 4 (1908) 467-89 ("i mali della Chiesa in Francia"; "si affannavano con un lavoro sterile a turare le falle pericolose, senza sospettare che il male era più profondo e radicale ed esigeva perciò dei rimedi radicali”). 
a Motu proprio that required all clerics to take an anti-Modernist oath. George Williams states that "La Piana is recorded as saying that he never had to sign the oath, perhaps because of the leniency of Cardinal Lualdi, perhaps because of the quasi-municipal status of San Rocco."24

This meant that at that time everyone suspected of Modernism was put on a list of sympathizers, which was kept in the Roman offices and barred them from any advancement in an ecclesiastical career. They were sent off to small parishes in rural districts out of contact with intellectual life and condemned to isolation. They faced a harsh dilemma: either to submit and be condemned to intellectual marginalization or to leave the church and be confronted with the difficulty of beginning a new life. ${ }^{25}$ La Piana, who felt hemmed in by his native Sicily, considered going to live in Rome; later, in 1913, he took up the idea of going to Milwaukee in the United States, ${ }^{26}$ where three of his brothers had already moved. ${ }^{27}$ Buonaiuti wrote him a letter full of curiosity and concern about his friend's choice: "I look forward impatiently to your news from America . . . if you have found there an atmosphere better suited to your spiritual demands and more congenial to your personality and your plans, then I shall not question your decision to stay. I hope you will soon be assigned a teaching post worthy of your intelligence and your culture."28

The Unitarian pastor Lyman M. Greenman recommended La Piana to the Harvard Divinity School, where he met George Foot Moore ${ }^{29}$ and James Hardy Ropes. ${ }^{30}$ During the academic year 1918-1919, he taught his first course on Catholic moral theology, beginning with Saint Augustine. La Piana had sent Buonaiuti a draft of the course program and the latter replied that he had gone through it and

${ }^{24}$ Williams, Professor George La Piana (1878-1971), 128.

${ }^{25}$ Carlo Falconi, Gli spretati (Florence: Parenti, 1951) 203.

${ }^{26}$ In 1918, he obtained American nationality.

${ }^{27}$ Bedeschi states that La Piana was threatened with disciplinary measures because of his Modernist position and was thus obliged to emigrate (Lorenzo Bedeschi, "Un episodio di spionaggio antiModernista," Nuova rivista storica 61 [1972] 152-54).

${ }^{28}$ Ernesto Buonaiuti correspondence, 8 November 1913, Giorgio La Piana Papers, bMS 104, Andover-Harvard Theological Library, Harvard Divinity School ("Attendo con impazienza le tue nuove dall'America. . . . se hai trovato costì un ambiente più consono alle tue esigenze spirituali, più rispondente alla tua personalità, e ai tuoi propositi, non discuterò la tua decisione di restarvi. Spero che ti venga assegnato presto un posto di insegnamento proporzionato alla tua intelligenza e alla tua cultura").

${ }^{29}$ La Piana translated Foot Moore's book History of Religions (New York: Scribner's, 1913) into Italian for Laterza (1922). In 1925, the journal Ricerche Religiose published Moore's essay: "Il Giudaismo universalistico" 1 (1925) 118-31. La Piana probably translated the study.

${ }^{30}$ Salvatore Corso, "Giorgio La Piana (1878-1971). Un siciliano teologo 'Modernista d'America,"” Biblos 29 (2009) 51-73, at 53. See also Corso, "Giorgio La Piana. Carteggi e scritti di un siciliano 'Modernista d'America' (parte prima)," Bollettino della Badia Greca di Grottaferrata 7 (2010) 5-44; Corso, "Giorgio La Piana. Carteggi e scritti di un siciliano 'Modernista d'America' (parte seconda)," Bollettino della Badia Greca di Grottaferrata 8 (2011) 71-147. 
that it provided "a rich and at the same time harmonious overview." ${ }^{11}$ From that moment onward La Piana's career went on very smoothly: from 1919 to 1923 he was an instructor in church history; in 1923 he was appointed assistant professor, which he remained until 1932, when he became full professor of church history. In 1920, he founded an Institute in Boston for the promotion of Italian culture, which became a meeting place for many antifascists who had fled to the United States, amongst them Luigi Sturzo, Carlo Sforza, Luigi Venturi, Gaetano Salvemini, and Arturo Toscanini.

\section{La Piana, Buonaiuti, and Modernism}

In an April 1920 article published in the Harvard Theological Review under the title "The Roman Church and Modern Italian Democracy," La Piana stressed that, from ancient times to the present day, the Papacy's main agenda "has been and is the same: to control the complex whole of human life and social organization through spiritual power in order to ensure those conditions that alone can lead individual souls to eternal salvation." ${ }^{32}$ From the outset, La Piana's studies focused on the origins of the church's power in ancient Rome, persuaded as he was that

from the very beginning of Christianity in ancient Rome, the choice of the leaders, preachers and apostles was the privilege of the whole community - as established by the Apostles themselves. The spiritual powers and the laws of the community were not vested in the Koinonia, spiritual association, but were granted by the Spirit who descended on them. In other words, the community designated only those to be vested with powers but not the powers themselves. ${ }^{33}$

This implied that spiritual leaders represented the whole community in that such a role had been given to them by the community, thus making it clear that the very same role could be taken away. Persuaded of the importance of political-cultural matters in religious issues and facing the challenges introduced by Modernism, the scholar proved to be more and more convinced that temporal power must be placed in its historical context. ${ }^{34}$

La Piana concentrated on events in recent history, emphasizing the fact that "during the nineteenth century, Gioberti, Rosmini, Lambruschini, Curci were splendid illustrations of the everlasting vitality among the Italian clergy of a spirit of freedom and of reaction against the oppression of minds and consciences." The Italian Church's problems began with the "questione romana" (the Roman issue)

31 Ernesto Buonaiuti correspondence, 12 December 1917, Giorgio La Piana Papers, bMS 104, Andover-Harvard Theological Library, Harvard Divinity School ("un quadro ricco e nel medesimo tempo armonico").

${ }^{32}$ La Piana, The Roman Church and Modern Italian Democracy, HTR 13 (1920) 159-183, at 160.

33 "Education and vocation, including Monreale period," Giorgio La Piana Papers, bMS 104, Andover-Harvard Theological Library, Harvard Divinity School.

${ }^{34}$ Corso, "Giorgio La Piana (1878-1971). Un siciliano teologo 'Modernista d'America,"” 66-67. 
and "the fall of the temporal kingdom of the papacy completed Italy's political unity," together with the extreme measures adopted by Piedmontese law. The new government, La Piana complained, secularized the university, even abolishing theological Faculties, closed the Colleges of the religious orders, and reduced the Seminaria to the condition of private institutions, whose diplomas were deprived of any value as a title for admission to public office or public liberal professions. So, as La Piana wrote in the Harvard Theological Review, "while the public schools under the new regime of liberty were open to all modern ideas and scientific methods, the Seminaria not only stood by their methods, but through an inevitable reaction against the irreligious spirit of the public school, became even more conservative, thus producing an enormous gulf between the mentality of the new clergy and the young laymen growing up in the public school." 35

The first step towards the ruin of church culture was the imposition of scholastic philosophy as the only system of thought to be accepted and professed by the clergy. La Piana pointed out that "Catholic writers on Scholastic Theology do not hesitate to admit that no work contributing new and valuable additions to this science has been published since the days of Bellarmin, Suarez and Lugo." The "collapse" of scholastic philosophy after the fifteenth century obviously affected scholastic theology too, which, in losing all contact with "the new scientific progress also lost its strong appeal to speculative minds." ${ }^{36}$ In the early twentieth century, Thomism was not the only philosophy professed by the church, but "the experience of various theological adventures confirmed belief in the radical opposition of modern philosophy to the dogmatic tradition of the church, and suggested to the ecclesiastical government the need for a definite step to put an end to the philosophical wanderings of theologians." The encyclical Aeterni Patris, which urged Catholics to restore the study of scholastic philosophy and especially of Aquinas in their schools, was the natural conclusion of the trend that inspired the dogmatic work of the Vatican Council I. ${ }^{37}$

La Piana admitted that in some countries a "new reconstruction of Scholasticism in harmony both with the dogmatic teachings of the Church and with modern science" was taking place, as was evident, for example, in the intellectual debates taking place within the department of philosophy at the University of Louvain. Still, La Piana also stressed that most Catholic scholars "advocated the return to what may be called integral Thomism." Louis Billot professed the opinion that "all theological questions find their solution either directly or indirectly by deduction in Aquinate teaching." This theological school was characterized by its systematic determination to ignore the objections to traditional theories made

${ }^{35}$ Giorgio La Piana, "A Review of Italian Modernism,” HTR 9 (1916) 351-375, esp. 351-55.

${ }^{36}$ Giorgio La Piana, "Recent Tendencies in Roman Catholic Theology," HTR 15 (1922) 233-292, at 233 .

${ }^{37}$ La Piana, "Recent Tendencies in Roman Catholic Theology," 237-238. See also Giorgio La Piana, "From Leo XIII to Benedict XV," The American Journal of Theology 21 (1917) 175-92. 
as a consequence of modern biblical and historical criticism. Billot's conviction was that "the conclusions of Biblical criticism destroyed the historical basis of the Tridentine doctrine of inspiration" and that new studies of theology demolished much of the scholastic structure which was based on "fragmentary or adulterated patristic historical ground, by which the acts of the councils must be interpreted, and on a wrong estimation of the value of pontifical legislation, so grossly disfigured by forgeries and interpolations of which the medieval theologians who made the scholastic synthesis were not aware." 38

Reconsidering these issues many years later in the 1960s, La Piana pointed out a difference between Pius IX's and Leo XIII's Pontificates. Pius IX's Vatican, deprived of its temporal possessions, considered it impossible to reconcile the church and modern ideas (he thought that the Italian liberal state embodied the principles of modernity), but the church under Leo XIII tried to free itself from the fetters chaining it irrevocably to the past. In a series of encyclicals, Leo XIII set the basis for a reform program with some slight changes in administration and hoped to raise Catholic influence in the world. He addressed the clergy, "exhorting the young priests to dedicate themselves to serious work in the religious sciences and especially the study of history, with modern methods and full use of historical criticism."39

It should be emphasized that this opinion differed from the one La Piana had professed in the past. In 1916, in an article published by the Harvard Theological Review, he was critical toward Leo XIII:

The idea of democracy which Leo cherished and desired in practice was something different from what we call democracy. He wanted a democracy blindly obedient to papal direction. He did not realize that it was merely a paradox to try and organize a democracy with a social, economic and political program of its own, and at the same time to keep such a democracy under the strict control of an irresponsible and infallible authority. ${ }^{40}$

Moreover, in his 1917 essay "From Leo XIII to Benedict XV," La Piana also expressed a negative opinion of the concentration of power in the church, singling out the infallibility of the Pope, which made for unchecked theocratic power. Leo's mission regarding the education of the clergy and the organization of lay Catholics was also part of this project, which was energetically taken up again by Pius X, who even contemplated preserving the unity of the church by means of the codification and elimination of dissent. ${ }^{41}$

${ }^{38}$ La Piana, "Recent Tendencies in Roman Catholic Theology," 242-43. Billot, a Thomist philosopher and theologian, lectured in several Jesuit ecclesiastical universities and schools. He contributed to drawing up Pius X's encyclical Pascendi condemning Modernism. He became Cardinal in the Papal Consistory of 27 November 1911.

39 "Modernism," Giorgio La Piana Papers, bMS 104, Andover-Harvard Theological Library, Harvard Divinity School.

${ }^{40}$ La Piana, "A Review of Italian Modernism," 365-66.

${ }^{41}$ La Piana, "From Leo to Benedict XV," 174-77. 
It is probable that the change of opinion regarding Leo XIII derives from a more carefully considered evaluation of the events of his youth matured by La Piana in his later years. Having set aside his youthful fervor, and with the years of Modernist "militancy" well behind him, he came to a new, historically meaningful, deeper and more carefully meditated position. It should be emphasized that in the years of the Vatican Council II and the post-Council a series of studies was made of Pecci's Pontificate, which emphasized its innovative characteristics and its differences with respect to Pius IX's and Pius X's. ${ }^{42}$ What is certain is that both the fight against modernity, to which Pius IX had devoted a lifetime of energy, and the cautious openings of Leo XIII were insufficient to prevent one of the most profound crises since Luther's times from spreading through Catholic Europe between the end of the nineteenth and the beginning of the twentieth century. ${ }^{43}$ La Piana pointed out that: "the progress of Modernism began with Bible studies but soon spread over the whole history of thought and of ecclesiastical institutions. It was a gradual and coherent process from history to the scientific field and still more important it invaded the field of religious politics, both national and international." ${ }^{44}$ Modernism was born, therefore, in the context of exegetical studies, but then spread throughout the church and in the political field.

42 See Leo XIII and the Modern World (ed. Edward T. Gargan; New York: Sheed \& Ward, 1961); Giuseppe Togni, Il papa degli operai (Rome: Arte della Stampa, 1961); Gabriele De Rosa, "La Rerum Novarum e il suo tempo," Rassegna di politica e di storia 79 (1961) 3-24; Georges Jarlot, Doctrine pontificale et Histoire: l'enseignement social de Leon XIII, Pie X et Benoit XV (Rome: Presses Gregorienne, 1964). Bedeschi has recently emphasized that the Catholic innovators preferred to refer to Leo XIII's encyclicals, whilst the conservatives liked to quote Pius IX and Pius X (Lorenzo Bedeschi, L'antiModernismo in Italia. Accusatori, polemisti, fanatici (Cinisello: San Paolo, 2000) 102-3.

${ }^{43}$ There is a considerable bibliography dealing with Modernism. As regards French Modernism, the following are recommended: Émile Poulat, Histoire, dogme et critique dans la crise Moderniste (Paris: Casterman, 1962); Pierre Colin, L'audace et le soupçon. La crise Moderniste dans le catholicisme française (Paris: Desclée De Brouwer, 1997); Émile Goichot, Alfred Loisy e ses amis (Paris: Les editions du cerf, 2002). Regarding Modernism in England, please see Alexander Roper Vidler, A Variety of Catholic Modernism (London: Cambridge University Press, 1970). The following are more recent works: David G. Schultenover, A View From Rome: On the Eve of the Modernist Crisis (New York: Fordham University Press, 1993); Catholicism Contending with Modernity: Roman Catholic Modernism and Anti-Modernism in Historical Contexts (ed. Darrell Jodock; Cambridge, UK: Cambridge University Press, 2000); In wilder zügelloser Jagd nach Neuem. 100 Jahre Modernismus und AntiModernismus in der katholischen Kirche (ed. Hubert Wolf and Judith Schepers; Paderborn, Germany: Ferdinand Schöningh, 2009); Guido Verucci, L'eresia del Novecento. La Chiesa e la repressione del Modernismo in Italia (Turin: Einaudi, 2010); La condanna del Modernismo. Documenti interpretazioni, conseguenze (ed. Claus Arnold and Giovanni Vian; Rome: Viella, 2010); Modernismo. Un secolo dopo (ed. Luciano Vaccaro and Marco Vergottini; Brescia: Morcelliana, 2010).

44 “Modernism," Giorgio La Piana Papers, bMS 104, Andover-Harvard Theological Library, Harvard Divinity School. 
At the beginning of the new century, some young priests dissatisfied with Catholic culture were ready to devote themselves not only to the duties of ecclesiastical office but also to religious, scientific work with a sincere desire "to serve truth and goodness in the Church of Christ for the progress of humankind." This is how, in the 1960s, La Piana describes the religious crisis of the early twentieth century:

The Modernist movement was really still in the stage of formation. Its representatives had differing opinions, especially in matters of philosophy. A possible unity in tendencies could be found among the followers of pragmatism, which offered a possibility of inquiring into modern thought, reducing it to a simple proposition that could be easily refuted. Among the followers of Modernism could be found various currents of thought, but if they had a philosophy, it was that of pragmatism enriched by immanentism which was affected by mystical experiences in religious fields. A more radical group adopted a kind of diluted rationalism, a type of Christian rationalism which, however, very soon slipped into absolute rationalism..$^{45}$

Taking into consideration the whole of the European context, La Piana analyzed the religious crisis and concluded that "the best representative of the current was Loisy, a man of great value in Biblical studies, who started by defending Christianity against Harnack's well-known book on the essence of Christianity." He believed that "the defense of the Catholic system by Loisy was very eloquent and full of zeal, but it was based on the principle of historical evolution, a principle that was rejected by Catholic theology because it denied the absolute values of religion and above all did not accept the Catholic notion of Divine revelation." ${ }^{46}$ La Piana stressed that among the Modernists "imbued with light and mystical aspiration" was the Jesuit George Tyrrell, a convert to Catholicism, driven by an appreciation of the spiritual and moral values that he found in the Catholic tradition. With the persistence of an apostle of truth in possession of the immanent assistance of the spirit, Tyrrell lived in an atmosphere of pietism, growing further and further away from the forms of worship that Catholicism had introduced among the faithful. ${ }^{47}$

Likewise, in his 1916 essay, La Piana emphasized the different cultural characteristics of the Modernists, and specified that they were not "representative of a system of philosophy, they were not a sect, nor an organized body of reformers." Modernism was a spiritual attitude, a strong faith and a vivid enthusiasm, trying to galvanize "the dead religious spirit of the people." He continued: "Some of

${ }^{45} \mathrm{Ibid}$

${ }^{46}$ During the winter of 1900, Adolf Harnack (1851-1930), professor of church history at Berlin University, gave a series of lectures on the subject of the original substance of the Christian message. The lectures were collected in the book Das Wesen des Christentums (Leipzig: J. C. Hinrichs, 1902). Harnack was skeptical about subordinating the means of salvation to the church authorities, believing that the spirit was sufficient to attain the salvation of human beings. In reply, Loisy wrote his book L'Évangile et l'Église (Paris: Alphonse Picard et fils, 1902), which challenged the conclusions of the German Lutheran theologian, using the same scientific research criteria.

47 "Modernism," Giorgio La Piana Papers, bMS 104, Andover-Harvard Theological Library, Harvard Divinity School. 
these Modernists who had been converted to the Neo-Kantian philosophy found in the shadow of practical reason a private solution to any contradiction between the ideal and the historical development of the Church"; "others were attracted by Neo-Hegelian doctrines, then in great favor in Italian universities, and found in that philosophy their true and only religion"; "others took a different path. They were the followers of the philosophy of immanence." Maurice Blondel's 1893 book, $L$ ' action: essai d'une critique de la vie et d'une science de la pratique, had been the "new gospel for their spiritual life." 48

Modernism also spread in the Italian Catholic world, although in 1929 Jean Rivière argued that in the peninsula the movement was devoid of originality and owed a lot to thinking and studies from the other side of the Alps. ${ }^{49}$ This claim, put into a broader context by historical studies from the 1960s onwards by historians such as Michele Ranchetti, ${ }^{50}$ Pietro Scoppola,${ }^{51}$ and Lorenzo Bedeschi ${ }^{52}$ in particular, was not shared by La Piana either, who drew attention to his own direct religious experience. He wished to make it clear that:

Modernism in Italy differed in many ways from Modernism in France, Germany, and England where it had an intellectual character, essentially rebelling against the traditional method of ancient theology. In Italy, on the contrary, Modernism began with, or was at least closely connected to, political-social aspirations and purposes. The name of Romolo Murri is linked to the formation of democratic and Christian organizations. ${ }^{53}$

It is interesting to note that in 1916 La Piana's opinion of Murri was different, when he wrote that Christian democrats were not Modernists "in the true meaning of the word" ("Murri himself remained faithful to his Scholastic philosophy"). He admitted, however, that "the attempt to harmonize Catholicism and democracy necessarily led to considering the problem of the nature and the constitution of the Church from a different point of view to the traditional one taught by the clergy." 54 Here, too, it can be supposed that the change in opinion was due to the new studies then being carried out on Murri by an important scholar, don Bedeschi - founder, in 1964, of the Centro Studi per la Storia del Modernismo (Centre for the History

48 La Piana, “A Review of Italian Modernism," 370-71.

49 Jean Rivière, Le Modernisme dans l'èglise: ètude d'histoire religieuse contemporaine (Paris: Letouzey et Ané, 1929) 89-90.

${ }^{50}$ Michele Ranchetti, Cultura e riforma religiosa nella storia del Modernismo (Turin: Einaudi, 1963).

${ }^{51}$ Pietro Scoppola, Crisi Modernista e rinnovamento cattolico in Italia (Bologna: Il Mulino, 1963).

${ }^{52}$ Lorenzo Bedeschi, I cattolici disubbidienti (Napoli: Bianco, 1959); Bedeschi, Interpretazioni e sviluppo del Modernismo cattolico (Milan: Bompiani, 1975).

53 "Modernism," Giorgio La Piana Papers, bMS 104, Andover-Harvard Theological Library, Harvard Divinity School.

${ }^{54}$ La Piana, “A Review of Italian Modernism,” 369. 
of Modernism) at the University of Urbino - which identified Murri as one of the major exponents of Italian Modernism. ${ }^{55}$ La Piana was in touch with Bedeschi ${ }^{56}$ and thus knew of his studies and the new interpretations of Modernism supported by the Italian historian.

At the beginning of the twentieth century La Piana met Murri, ${ }^{57}$ but undoubtably the encounter that left the strongest mark on him was his meeting with Buonaiuti. In La Piana's own words, "An event that affected my whole life was meeting Ernesto Buonaiuti. In about 1905 through my old friend from the Seminary in Monreale, Antonino De Stefano, who was then in Rome studying at the Apollinare, I happened to have the chance of being introduced to Buonaiuti." La Piana's opinion of Buonaiuti's intellectual and human stature did not alter with time; in the 1960s, he wrote that the Roman priest was "a great scholar and at the same time a man of action and a fascinating guide." La Piana emphasized the fact that Buonaiuti was "the true leader of Modernism in Italy" and "was influenced by the Modernists on the far side of the Alps, especially by Loisy and Tyrrell." 58

From the very beginning, the relationship between the two intellectuals was most intense and La Piana published several essays in the monthly journal edited by Buonaiuti, Rivista storico-critica delle scienze teologiche ${ }^{59}$ His connection with Buonaiuti is also apparent in the similarity of the historical themes they studied and from the reading of historical events carried out by La Piana, which were obviously conditioned by his intellectual affinity with the Roman scholar.

Both the Roman priest and La Piana focused on the power of the Roman institutions from the first few centuries of Christianity onwards. The Harvard scholar analyzed the Church of Rome in his 1921 essay "The Tombs of Peter and Paul ad catacumbas," which questioned the tradition holding that the church had been founded by two apostles, basing his arguments on New Testament and patristic

55 See Lorenzo Bedeschi, Il Modernismo e Romolo Murri in Emilia Romagna (Parma: Guanda, 1967). The review "Fonti e documenti" of the Centro Studi sul Modernismo, Bedeschi (1915-2006) published some pages of La Piana's autobiography, kept at the Andover-Harvard Theological Library. "La figura di Giorgio La Piana e le sue carte di Harvard," Fonti e documenti 31-32 (2002-2005) 77-99.

${ }^{56}$ In don Bedeschi's archive, there are two short letters from La Piana to the Italian historian. The first dates from 10 November 1965. The second is dated 11 December 1967 and was sent by La Piana to thank Bedeschi for having forwarded him his book Il Modernismo e Romolo Murri in Emilia Romagna. The archive, which I was able to consult while Bedeschi was still alive, is now kept at the University of Urbino but not yet catalogued and therefore not available to scholars.

${ }^{57}$ At the Romolo Murri Archivio (Fondazione Romolo Murri, Università di Urbino) some brief letters from La Piana to Murri are conserved.

58 "Modernism," George La Piana Papers, bMS 104, Andover-Harvard Theological Library, Harvard Divinity School.

59 Giorgio La Piana, "Chiesa e Stato in Francia. Progetti di riforme sui principi del sec. XVIII," Rivista storico critica di scienze teologiche 4 (1908) 467-89; 4 (1908) 553-80; 4 (1908) 667-86. La Piana, "Una relazione inedita del Nunzio apostolico nella Francia del XVIII secolo," Rivista storico-critica delle scienze teologiche 5 (1909) 1-23; La Piana, "Una omelia inedita di S. Gregorio Nisseno," Rivista storico-critica delle scienze teologiche 5 (1909) 1-39. 
texts as well as on the results of historical research. ${ }^{60} \mathrm{He}$ later emphasized the fact that nationalist Judaic elements (bringing with them the idea of "exclusivism") had converged in the Church of Rome as well as the mysteriosophic religions (with an aspiration towards universality). La Piana stressed that Christianity, which claimed to be the one true religion, destined to conquer the world, had directed all of its energies towards conserving unity of doctrine and practice of the sacraments. This unity, however, implied excommunication and the denial of any differentiation or debate in the Christian world. For La Piana, as for Buonaiuti, the church's main problem was the abandonment of the missionary vocation that had characterized the immigrant groups - and this had happened when the institutions assumed a juridical and organizational status. ${ }^{61}$

La Piana took up the issue again in his essay "La prima comunità cristiana di Roma e l'epistola ai Romani" (The first Christian community in Rome and the epistle to the Romans) published in 1925 in Buonaiuti's journal Ricerche Religiose. ${ }^{62}$ But it was mainly in his article "L'immigrazione a Roma nei primi secoli dell'Impero" (Immigration to Rome in the early centuries of the Empire) that the scholar dealt with the crucial matter of Christianity's passage from its missionary origins to its institutional form. La Piana focused on groups of immigrants, stressing that, as bearers of cultural diversity, they were badly received by the Romans, who treated them with "hostility mixed with contempt," partly because they belonged to races that the native population considered "inferior in terms of civilization and progress." ${ }^{3}$ The scholar declared that his objective was to understand why, "amongst the various religions with eastern origins that had moved to Rome, only Christianity managed to Romanize so perfectly." This came about because, unlike other cults, Christianity managed to widen gradually its sphere of action and penetrate into the social and political institutions. In other words, Christianity managed to develop its own organization, finally creating a "solid hierarchical unity," elaborating a "political-social agenda and thus replacing the old State religion." 64 This, however, gave rise to a profound transformation in Christianity itself, "through a process of adaptation of its principles and original agenda to its new and dangerous function as a State religion in the formal context

${ }^{60}$ Giorgio La Piana, "The Tombs of Peter and Paul ad Catacumbas," HTR 14 (1921) 53-94.

${ }^{61}$ Giorgio La Piana, Il Problema della Chiesa latina in Roma (Rome: Libreria di cultura, 1922) $22-34$

${ }^{62}$ Giorgio La Piana, "La primitive comunità Cristiana di Roma e l'epistola ai romani (prima parte)," Ricerche Religiose 1 (1925) 209-26; (seconda parte) 305-26.

${ }^{63}$ Giorgio La Piana, "L'immigrazione a Roma nei primi secoli dell'Impero (parte prima)," Ricerche Religiose 2 (1926) 485-547, at 517-18 ("ostilità mista di disprezzo;" "inferiori in civiltà e progresso").

${ }^{64}$ Giorgio La Piana, "L'immigrazione a Roma nei primi secoli dell'Impero (parte seconda)," Ricerche Religiose 3 (1927) 36-75, at 70-74 ("tra le varie religioni di origine orientale che si erano trapiantate a Roma, solo il Cristianesimo fosse riuscito a romanizzarsi perfettamente;" "salda unità gerarchica;" "a romanizzarsi completamente tanto nel suo spirito quanto nella sua organizzazione esterna"). 
of the political and social institutions of Rome." ${ }^{65}$ The scholar was aware that for Christianity this was the only way to become a universal religion, but he regarded this trend with suspicion. The emergence of a centralizing ecclesiology, already in existence in some apologetics, had become more distinct with Augustine, who elaborated the theory of the "régime of Christianity." ${ }^{66}$ Subsequently, in the west with Thomas Aquinas, an intellectual philosophy took root, or the tendency towards philosophical-theological speculation. ${ }^{67}$

La Piana's themes were close to Buonaiuti's and his line of interpretation was analogous. The American scholar admitted:

His influence over my way of thinking was considerable. As a matter of fact, I came to share his vision of spiritual life leading to a mystical conception of spirituality. A difference, however, between our two views was maintained. Fundamentally, I follow the philosophical traditions prevailing throughout many centuries in southern Italy and going back to the ancient Greek schools and I was led to a view which might be called rationalistic or rigidly syllogistic, while Buonaiuti was led by his mystical bent to accept a voluntaristic emotional element which escaped my philosophical system. . . At any rate, these differences of thought did not spoil our warm friendship, which lasted more than fifty years. The influence of his emotional and mystical explanation of life put a great deal of water into the wine of my rationalism. ${ }^{68}$

\section{The Church and the Outlawing of Dissent}

Until Pius X's encyclical Pascendi Dominici gregis, the different souls of Catholicism continued to coexist in the church, though with increasing difficulty. After September 1907, all of this changed, because any theories of scientific development incompatible with the beliefs of the church were condemned in the papal document: in philosophy immanence was banned, in theology criticism and subjectivism, in the field of Bible studies historical religious evolution and the application of positivist criticism. ${ }^{69}$ La Piana, who in 1907 had already suffered from the accusations against Catholics innovators, focused on this issue in the 1960s. He emphasized the fact that the intention of the encyclical was

${ }^{65}$ Ibid. ("attraverso un processo di adattamento dei suoi principi e dei suoi programmi originari alla nuova e pericolosa funzione di religione di stato, inquadrata nelle istituzioni politiche e sociali di Roma").

${ }^{66}$ Giorgio La Piana, "The Roman Church at the End of the Second Century," HTR 18 (1925) 201-277.

${ }^{67}$ Giorgio La Piana, “Ancient and Modern Christian Apologetics,” HTR 24 (1931) 1-27.

68 "Modernism," Giorgio La Piana Papers, bMS 104, Andover-Harvard Theological Library, Harvard Divinity School.

${ }^{69}$ Jean Baptiste Lemius, Catéchisme sur le Modernism: d'apres l'Enciclique Pascendi Dominici gregis de S. S. Pie X (Paris: Librairie saint Paul, 1907) 67-79. 
to show that the Modernist movement derived its characteristics not from intellectual and moral demands, but from principles and philosophical systems already condemned by the Church. According to the encyclical, the paternity of Modernism was to be found in anti-Christian philosophies and especially in rationalism, positivism and in immanentism, all currents of thought which combined to make up a coalition of triumphant pragmatism. ${ }^{70}$

La Piana then described the impact that the encyclical had on the Catholic world:

Pius X condemned the Modernists, as they came to be called, and excommunicated the rebels. They knew that all hope of advancement in their career was lost. Those who rebelled were deprived of all their rights and excluded from the priesthood. They were forced to struggle for their living in some secular concern. A few, very few, remained in the Church but continued their work under various guises, keeping up, however, the appearance of orthodoxy. $^{71}$

The Roman Curia, the Sant'Uffizio (the institution that replaced the Inquisition from 1908 onwards), and the Secretary of State demonstrated that they were committed to repressing any reaction to the encyclical. The various protagonists of the Modernist movement assumed differing attitudes: Salvatore Minocchi decided to suspend the publication of his Studi religiosi, the first Italian journal of biblical exegeses, founded in Florence in $1901 .^{72}$ The review Rinnovamento (founded in 1907 by Tommaso Gallarati Scotti, Alessandro Casati, and Stefano Jacini) reacted against the encyclical and criticized it for not distinguishing between the various philosophical currents of Catholic innovators. ${ }^{73}$ Tyrrell criticized the arbitrary way that Catholicism and scholastic philosophy were identified as one and the same in the Pascendi but, above all, maintained that the new direction taken by the Pope prevented any revival of Catholic spirituality in the contemporary world..$^{74}$ In March 1908, Loisy, who had refused to submit to the Pope's instructions, was excommunicated. Murri, who had taken a Thomist position, argued that the encyclical's condemnation did not include him, thus incurring Buonaiuti's protests. ${ }^{75}$ In order to defend the ideas professed by the religious reform movement, Buonaiuti decided to write the pamphlet Programma dei Modernisti (the Modernists' program), which upheld the need to fill the "empty space" between the assertions of official theology and historical investigation through a reexamination of

\footnotetext{
70 "Modernism," Giorgio La Piana Papers, bMS 104, Andover-Harvard Theological Library, Harvard Divinity School.

71 Ibid.

${ }^{72}$ See Salvatore Minocchi, Memorie di un Modernista (Florence: Vallecchi, 1974) 92-100.

73 "Intorno al Modernismo," Rinnovamento 2 (1908) 364-76.

${ }^{74}$ George Tyrrell, Medievalism. A Reply to Cardinal Mercier (London: Logmans, Green and Co., 1908). See also Autobiography and Life of George Tyrrell (London: Edward Arnold, 1912) 65-71.

${ }^{75}$ Giacomo Losito, "Il Modernismo e la sua repressione," in Cristiani d'Italia. Chiese, società, Stato 1861-2011 (Rome: Istituto dell'Enciclopedia italiana, 2011) 237-45.
} 
Christianity's essential values. ${ }^{76}$ The Roman priest returned to the subject in his autobiography, published in 1945, maintaining that the Pascendi had been "in the history of the Roman Pontificate's public manifestations, one of the gestures that had had the widest and most destructive repercussions." To quote Buonaiuti's powerful metaphor, "the encyclical swept through the cornfields of the nation's spirituality like a devastating wind, quickly drying them all up."77

Buonaiuti remained in the church and won an appointment as full professor of the history of Christianity at the University of Rome in 1915. In a letter to La Piana, the Roman priest writes that he has begun his university course in a favorable atmosphere. Later, after outlining the topics he plans to address, Buonaiuti assures him that as soon as he has a text ready, he will let him have a copy. ${ }^{78}$ The lectures were collected in the volume Il cristianesimo nell'Africa romana, which takes into consideration the contribution of the African experience to the transformation of imperial Rome. It was no coincidence that the priest considered his American friend's opinion important, since the topics he was dealing with were familiar to La Piana. In his autobiography, Buonaiuti stressed this common interest and how La Piana,

through a minute and shrewd investigation of the ethnic and moral structure of the first two centuries of imperial Rome, had succeeded in obtaining a clear idea of the importance the African element had had in Rome in setting up the first Roman school. For myself, I recorded the content of writings from the African Church to Christianity and pointed out what we had inherited from them in the fields of ritual, religious theory and discipline. ${ }^{79}$

Moreover, in 1917, La Piana translated and published the articles "The Genesis of St. Augustine's Idea of Original Sin" and "The Ethics and Eschatology of Methodius of Olympus" in the Harvard Theological Review. ${ }^{80}$

From 1917 onwards, a Christian community formed around Buonaiuti, the so-called Koinonia, which consisted of a group of disciples who met the priest every Sunday in Rome (and during the summer at the San Donato hermitage, near Subiaco) and included, amongst others, Raffaello Morghen, Alberto Pincherle, Ambrogio Donini, Mario Niccoli, Giorgio Levi Della Vida, and Arturo Carlo Jemolo. Their meetings were based on study, conversation, the reading of the New

${ }^{76}$ Programma dei Modernisti (Turin: Bocca, 1908).

${ }^{77}$ Ernesto Buonaiuti, Pellegrino di Roma (Rome: Darsena, 1945) 91-92.

${ }^{78}$ Ernesto Buonaiuti correspondence, 1915, Giorgio La Piana Papers, bMS 104, Andover-Harvard Theological Library, Harvard Divinity School.

${ }^{79}$ Buonaiuti, Il pellegrino di Roma, 142 ("attraverso esplorazioni minute e sagacissime nella struttura etnica e morale della Roma imperiale dei primi due secoli, fosse giunto ad una delimitazione luminosa dell'apporto dell'elemento africano a Roma, nella instaurazione del magistero primaziale romano. Io per conto mio registravo i contenuti letterari della Chiesa africana al cristianesimo e segnalavo l'eredità da essa lasciata nel campo rituale, teorico-religioso, disciplinare").

${ }^{80}$ Ernesto Buonaiuti, "The Genesis of St. Augustine's Idea of Original Sin," HTR 10 (1917) 159-75; "The Ethics and Eschatology of Methodius of Olympus," HTR 14 (1921) 255-66. 
Testament and ecclesiastical authors, and the discussion of contemporary thinkers and issues.$^{81}$ Morghen writes that Buonaiuti intended "to place the emphasis on the religious experience of the first Christian communities from a historical point of view," without, however, yielding to the temptation of "theological indoctrination," because "the greatest freedom" was the rule of the group. ${ }^{82}$

Although living thousands of kilometers away, La Piana was close enough to the members of the cenacle that he exchanged letters not only with Buonaiuti but also with other members of the group. In 1921, young Alberto Pincherle ${ }^{83}$ confessed to La Piana, "As for myself, I am not a practicing Jew at all. Whilst linked to the religious traditions of my race, and to those aspects that may still be alive in them, my present spiritual inclination is very close to that of Prof. Buonaiuti. My devotion to him and the friendship that unites me with the other members of the nucleus surrounding him are, I think, clear proof of how I feel, without having to go into it any further. ${ }^{84} \mathrm{He}$ added his thoughts on the religious situation and explained that, "in Italy, given the attitude of the Catholic Church, so resolutely and tenaciously opposed to our studies, very few people take an interest in these issues." ${ }^{85}$ Pincherle asked La Piana if it was possible to study in United States, and in fact, in 1921, the latter obtained a scholarship for him. ${ }^{86}$ The young man remained in Cambridge until June 1922.

${ }^{81}$ Carlo Fantappiè, Arturo Carlo Jemolo. Riforma religiosa e laicità dello Stato (Brescia: Morcelliana, 2011) 21-22. See also Annibale Zambarbieri, "La Koinonìa di Ernesto Buonaiuti," Humanitas 56 (2001) 213-30; Una rete di amicizie. Carteggi dalla Koinonia di Ernesto Buonaiuti (ed. Ottavia Niccoli; Rome: Viella, 2014); Francesco Torchiani, L'oltretevere da oltreoceano (Rome: Carocci, 2015) 67-73.

${ }^{82}$ Raffaello Morghen, "Il Modernismo e la storia del cristianesimo di Ernesto Buonaiuti," in Ernesto Buonaiuti storico del cristianesimo (Rome: Istituto storico italiano per il Medioevo, 1978) 10-14, at 11-12 ("mettere in evidenza, da un punto di vista storico, l'esperienza religiosa delle prime comunità cristiane"; "indottrinamento teologico"; "la più grande libertà").

${ }^{83}$ Alberto Pincherle (1894-Rome 1979) was a university professor of the history of Christianity. His works include: Detti di Gesù (1922); Gli oracoli sibillini giudaici (1922); S. Agostino d'Ippona (1930); La formazione teologica di s. Agostino (1947); Cristianesimo antico e moderno (1955); Introduzione al cristianesimo antico (1971); Vita di s. Agostino (1980).

${ }^{84}$ Alberto Pincherle correspondence, 9 April 1921, Giorgio La Piana Papers, bMS 104, AndoverHarvard Theological Library, Harvard Divinity School ("Per ciò che mi riguarda personalmente, non sono affatto un ebreo praticante. Legato alla tradizione religiosa della mia razza, in ciò che può avere ancora di vivo, il mio indirizzo spirituale è per altro assai vicino a quello del prof. Buonaiuti. La devozione che ho per lui e l'amicizia che mi unisce agli altri componenti il nucleo che gli sta d'intorno, credo che le dimostri chiaramente il mio modo di sentire, senza che mi dilunghi").

${ }^{85}$ Alberto Pincherle correspondence, 9 April 1921, Giorgio La Piana Papers, bMS 104, AndoverHarvard Theological Library, Harvard Divinity School ("in Italia, dato 1'atteggiamento della Chiesa cattolica, risolutamente e tenacemente avversa ai nostri studi, le persone che si occupano di questi temi sono in piccolissimo numero").

${ }^{86}$ Alberto Pincherle correspondence, 12 July 1921, Giorge La Piana Papers, bMS 104, AndoverHarvard Theological Library, Harvard Divinity School. 
Encouraged by the Italian publishers Campitelli of Foligno (near Perugia), Buonaiuti agreed in 1923 to direct the "Biblioteca di storia religiosa" (Religious History Library), a series that published books on the historical development of religion. When drawing up a list of possible co-workers, the priest included La Piana's name (as well as Jemolo, Levi Della Vida, Pincherle, Luigi Salvatorelli, Giuseppe Tucci, Nicola Turchi and Umberto Fracassini). ${ }^{87}$

In 1926, La Piana returned to Italy, where he was Buonaiuti's houseguest in Rome. A year earlier, on 25 January $1925,{ }^{88}$ the latter had been excommunicated for his defense of the Modernist movement. La Piana's visit had been long awaited by his friends and Buonaiuti wrote: "The prospect of having you here in Rome with us, very soon and for an extended period, organizing our program with us, cheers and encourages us." 89 During his stay in Italy, both in the capital and in the hermitage of San Donato, he had the opportunity to meet Buonaiuti's friends and disciples. In a letter sent to La Piana on 27 November 1926, Jemolo wrote ${ }^{90}$ :

I would very much have liked to have a longer talk with you: both because I would have liked to ask you many questions and learn from you, and because I wanted to talk a little about this Catholic world of ours in Italy, which must have made such a poor impression but which harbors some small veins of precious metal, the same as eighty years previously, although today there is no Lambruschini or Aporti or even a Taparelli to raise his head! ${ }^{91}$

${ }^{87}$ Letter from Buonaiuti to Jemolo, Rome 17 April 1923, in Lettere di Ernesto Buonaiuti a Carlo Arturo Jemolo (1921-1941) (ed. Carlo Fantappiè; Rome: Ministero per i Beni Culturali, 1997) 69-70.

88 In 1925, Buonaiuti wrote: "I could say that for about fifteen years now my bitter existence has been an expiation for my youthful dream of raising Italian Catholic culture to the same level as foreign studies in the religious sciences" (Una fede e una disciplina [Foligno: Campitelli, 1925] 33).

89 Ernesto Buonaiuti correspondence, 20 January 1926, Giorgio La Piana Papers, bMS 104, Andover-Harvard Theological Library, Harvard Divinity School ("La prospettiva di averti presto, e per un lungo periodo, qui a Roma con noi alla organizzazione del nostro programma, ci rallegra e ci incoraggia").

${ }^{90}$ Arturo Carlo Jemolo (1891-1981), a law graduate in 1911 from the University of Turin, he was professor of Canon Law at the universities of Sassari, Bologna, Cattolica di Milano and Rome, up to 1961 . In 1931, he was amongst the few university lecturers who did not sign the oath of loyalty imposed by the Fascist regime.

91 Letter from Jemolo to La Piana, 26 November 1926, Giorgio La Piana Papers, bMs 104/34, Andover-Harvard Theological Library, Harvard Divinity School ("Avrei avuto molto caro di poter parlare un po' a lungo con lei: sia perché molte cose avrei desiderato chiederle ed apprendere, sia perché avrei anche voluto parlarle un po' di questo nostro mondo cattolico italiano, che deve averle fatta una così penosa impressione, ma che contiene in sé qualche piccolo filone di metallo prezioso, gli stessi che conteneva ottant'anni or sono, seppur oggi non levino il capo né un Lambruschini né un Aporti, e neppure un Taparelli!’). 
Mario Niccoli also kept up relations with the "American professor" and in 1927 sent him a letter in which the younger man referred to a book that had just been published on Modernism. ${ }^{92}$ He wrote: "sincerely, while reading these pages in which we sense barely concealed and nameless suffering and, most importantly, endless faith in the triumph of an idea, tears often came to my eyes at the thought that we shall have to work with just as much faith and courage to ensure that the struggle bears fruit." 93

In 1929, when the Lateran Treaties were signed between the Italian state and the Holy See, La Piana expressed his perplexity, considering them baleful, mutual concessions between two different kinds of totalitarianism. Convinced of the need to separate the areas and interests of the state from those of the church, a conviction he had already voiced in his 1909 essay in Buonaiuti's journal Rivista storico-critica di scienze teologiche,${ }^{44}$ he declared himself contrary to the Concordat. Moreover, in articles written with Gaetano Salvemini, and collected in the volume What To Do With Italy, the two antifascists wrote: "The cornerstone of modern democracy consists in freedom of conscience and religion for everyone. Without this freedom, there is no democracy." 95

A regulation in the Concordat, recommended by Cardinal Pietro Gasparri (Pius XI's Secretary of State), was conceived especially to punish Buonaiuti. It ruled that an excommunicated priest could not teach in Italian universities. Thus, Buonaiuti was deprived of his teaching post and was given the task of studying the figure of Gioacchino da Fiore, a topic the Roman scholar considered "immensely, indeed fully satisfying," because this figure was "very little known." 96 At the annual meeting in April 1930 of the Medieval Academy of America, and thanks to La Piana's recommendations, Buonaiuti was awarded the Edward Kennard Rand prize for

92 On this topic, Piero Gobetti, who was interested in the thought of the French Catholic Modernists Blondel and Laberthonniére, published Opera critica (Turin: Baretti, 1927). The book was published posthumously, after his death in France in 1926 at the hands of a fascist squad.

${ }_{93}$ Mario Niccoli correspondence, 5 May 1927, Giorgio La Piana Papers, bMS 104, AndoverHarvard Theological Library, Harvard Divinity School ("veramente leggendo quelle pagine attraverso le quali mal sono celate sofferenze senza nome e soprattutto una fede senza confini nel trionfo di una idea, mi sono venute spesso le lacrime agli occhi al pensiero di quanto sia necessario lavorare con altrettanta fede e con altrettanto coraggio perché la lotta porti si suoi frutti fecondi”).

${ }^{94}$ Giorgio La Piana, "Chiesa e Stato in Francia. Progetti di riforme sui principi del sec. XVIII," Rivista storico-critica delle scienze teologiche 4 (1908) 467-89.

${ }^{95}$ Gaetano Salvemini, Giorgio La Piana, What To Do With Italy (New York: Duell, Sloan and Pearce, 1943) ("La pietra angolare della democrazia moderna consiste nella libertà di coscienza e di culto per tutti. Senza queste libertà non vi è democrazia").

${ }^{96}$ Letter from Buonaiuti to Missir, Rome, 4 February 1928, in Ernesto Buonaiuti, La vita allo sbaraglio. Lettere a Missir (1926-1946) (ed. Ambrogio Donini; Florence: Nuova Italia, 1980) 51-54 ("di grandissima e pienissima soddisfazione" and "pochissimo conosciuto"). 
his studies of Gioacchino. ${ }^{97}$ La Piana also shared Buonaiuti's interest in medieval theology; he published, in 1931, the book Gioacchino da Fiore. I tempi, la vita, il messaggio ${ }^{98}$ and, in 1932, an article in the journal Speculum. ${ }^{99}$

In a 1929 letter, Niccoli spoke to La Piana about Buonaiuti and about the discrimination he was experiencing as a result of the Concordat: "it is unlikely the Professor will ever be able to teach again. At best, he will be remembered forever in his own parish and the course in Rome University on the History of Christianity might be opened for teaching applications. But it is absurd to think that Buonaiuti may return to teaching without the consent of the church authorities, which will never be given." In his letter Niccoli also referred to Ambrogio Donini, whose whereabouts everyone in Rome was "anxious to know." ${ }^{100}$ After graduating, Donini, also a pupil of Buonaiuti's, obtained a scholarship at the Divinity School for the academic year 1928-1929 thanks to La Piana. ${ }^{101}$ The following year, Donini went to teach at Brown University in Providence, Rhode Island, and in 1930-1931 he taught at Smith College in Northampton, Massachusetts. Unknown to Buonaiuti and La Piana, Donini had actually decided to go to the United States at the suggestion of a Communist group, which encouraged him to leave Italy and make contact with the party's foreign nucleus. This is why the young man soon became clandestine, arousing the concern of his friends in Rome. ${ }^{102}$ At the end of 1931, he was recalled to Europe by the PCI (Italian Communist Party). ${ }^{103}$

Buonaiuti's misadventures were not over, since in 1931 he was dismissed from the Italian university as a consequence of his determination not to swear loyalty to the fascist regime. Only twelve lecturers followed Buonaiuti's example. The twelve included Levi Della Vida who, in 1924, had already signed the Appeal by AntiFascist Intellectuals and was a renowned scholar of Islamic culture. A prestigious Italian professor, Della Vida lost his university post and contacted his friend La

${ }^{97}$ Buonaiuti, La vita allo sbaraglio. Lettere a Missir (1926-1946), 163.

${ }^{98}$ Giorgio La Piana, Gioacchino da Fiore. I tempi, la vita, il messaggio (Rome: Collezione meridionale, 1931). See Marina Benedetti, "Eresie medievali ed eretici modernisti," La riforme della Chiesa nelle riviste religiose di inizio Novecento (ed. Marina Benedetti and Daniela Saresella; Milan: EBF, 2010) 313-30.

${ }^{99}$ Giorgio La Piana, “Joachin of Flora: A Critical Survey,” Speculum 7 (1932) 257-82.

${ }^{100}$ Mario Niccoli correspondence, 29 March 1929, Giorgio La Piana Papers, bMS 104, AndoverHarvard Theological Library, Harvard Divinity School. See Daniela Saresella, Cattolici a sinistra. Dal Modernismo ai giorni nostri (Rome-Bari: Laterza, 2011) 42-47 ("difficilmente il professore potrà mai più tenere un insegnamento. Nella ipotesi migliore egli sarà ricordato in eterno al suo vicario e la cattedra di Roma di Storia del cristianesimo potrebbe anche essere messa a concorso. Infatti è assurdo pensare che Buonaiuti possa tornare a insegnare senza il consenso dell'autorità ecclesiastica che non verrà mai"; "ansiosi di conoscere").

${ }^{101}$ Donini, in his autobiography, described La Piana as an "amico e confratello di Buonaiuti" (friend and brother of Buonaiuti) (Ambrogio Donini, Sessant'anni di militanza comunista [Milan: Teti, 1988] 81-82).

${ }^{102}$ Buonaiuti, Il pellegrino di Roma, 352. See also Ambrogio Donini, Sessant'anni di militanza comunista, 13.

${ }^{103}$ Donini (1903-1991), after World War II, was also elected Senator in the Communist Party lists. 
Piana to see if there were any opportunities available to him in the United States. In 1933, La Piana asked John Marshall of the Rockefeller Foundation for help in finding Della Vida a position. ${ }^{104}$ The attempt was unsuccessful because, as Marshall wrote to La Piana, "unfortunately, Della Vida's work does not fall within any of the fields which we can now assist." 105 After the racial laws were passed in Italy in 1938, Levi Della Vida managed to migrate to the United States, where he obtained a teaching post at the University of Pennsylvania and then at the University of San Diego, California. Before his death, he donated his own collection of books to the Arab-Islamic section of the University of San Diego library. Contacts between the two scholars continued up to the end of the 1950s (Levi Della Vida's last letter to La Piana dates back to December 1959) ${ }^{106}$ in the context of a close intellectual and human relationship.

In 1938, La Piana also made efforts to find work in the United States for Pincherle, who had asked him for help; ${ }^{107}$ since he was Jewish, the latter had lost his teaching position of History of Religion at Cagliari University. The problem for the Italian scholar was not so much to find a job-Kirsopp Lake wrote to La Piana saying that he had found something for Pincherle ${ }^{108}$ - as to obtain the permit to enter the United States. Thus, in 1939, he migrated to Lima, Peru, where he taught at the Pontificia Università Cattolica di San Marcos, not returning to Italy until November 1946. ${ }^{109}$

\section{Conclusions}

With the fall of fascism (on 25 July 1943) and the liberation of Rome by the Anglo-Americans (in June, 1944) a democratic regime was re-established in the center and south of Italy, whilst in the German-occupied north, Mussolini and his Repubblica Sociale Italiana were as yet undefeated. In the Regno del Sud (the South), the university professors who refused to swear loyalty to fascism in 1931 were reinstated, but Buonaiuti's own problems were not over; he was prevented from returning to teaching because the Concordat was still in force. Dismayed, the

104 John Marshall correspondence, 21 September 1933, Giorgio La Piana Papers, bMS 104, Andover-Harvard Theological Library, Harvard Divinity School. See Giovanni Rota, "Un'oncia di buon senso. Giorgio Levi della Vida e il fascismo," in Giorgio Levi della Vida (ed. Enrico Rambaldi and Giovanni Rota; Milan: LED, 2010) 95-153.

105 John Marshall correspondence, 14 February 1934, Giorgio La Piana Papers, bMS 104, Andover-Harvard Theological Library, Harvard Divinity School.

${ }^{106}$ Giorgio Levi Della Vida correspondence, 22 April 1959, Giorgo La Piana Papers, bMS 104, Andover-Harvard Theological Library, Harvard Divinity School.

${ }^{107}$ Alberto Pincherle correspondence, 18 October 1938, Giorgo La Piana Papers, bMS 104, Andover-Harvard Theological Library, Harvard Divinity School.

${ }^{108}$ Kirsopp Lake correspondence, 20 December 1938, Giorgo La Piana Papers, bMS 104, Andover-Harvard Theological Library, Harvard Divinity School.

${ }^{109}$ Alberto Pincherle correspondence, 21 April 1939, Giorgo La Piana Papers, bMS 104, AndoverHarvard Theological Library, Harvard Divinity School. 
Roman historian wrote to La Piana: "I have already been warned that the Vatican has again opposed my return to teaching," thus thwarting any hope of change and freedom to come. ${ }^{110}$ La Piana replied, shocked, "I can't tell you how indignant I am at the behavior of those pigs regarding your reinstatement in university." 111

Buonaiuti lived in poverty until his death on 20 April 1946 and, as Niccoli concluded, "in those years Buonaiuti certainly didn't lead an easy life."112 At the inauguration of the academic year 1946-1947 (the last in La Piana's teaching career), La Piana, who had always remained in contact with Buonaiuti, ${ }^{113}$ gave a speech commemorating his friend. ${ }^{114}$ His words were used as the introduction to a book by Buonaiuti, La vita dello spirito, which the Roman publisher De Carlo decided to publish in view of his "knowledge of the religious texts and his friendship with Buonaiuti." 115 La Piana considered Buonaiuti to be close to John Henry Newman, because they shared a belief in the evolution of dogma, and to Tyrrell, because both cared about human spirituality as against a static religion. Referring to his friend's thought, La Piana wrote: "In the light of history the so-called dogmas of the Church are transcriptions of concepts and are conditioned by the thought and language of their time and environment." Buonaiuti thought that it was inevitable for Christian religious beliefs to be transcribed in conceptual forms, but when this happened they lost their contact with the original prophetic and mystical nature of Christianity." La Piana then emphasized how "Buonaiuti's vision of Christian spiritual life was entirely dominated by the mystical anti-intellectual notion of the original Christian message." 116 Pincherle approved of the commemoration and wrote to La Piana: "It is truly fine, alive, warm and full of understanding: perhaps the best of what has been written about him - so fine that I am translating it, so that part of it can be published in Ricerche religiose." 117

${ }^{110}$ Ernesto Buonaiuti correspondence, 11 September 1944, Giorgo La Piana Papers, bMS 104, Andover-Harvard Theological Library, Harvard Divinity School ("Già sono stato avvertito che il Vaticano si è nuovamente opposto al mio ritorno all'effettivo insegnamento").

${ }^{111}$ Ernesto Buonaiuti correspondence, 15 January 1945, Giorgio La Piana Papers, bMS 104, Andover-Harvard Theological Library, Harvard Divinity School. This is a copy of the letter sent by La Piana to Buonaiuti ("Non ti posso dire quanta sia la mia indignazione per la condotta di quei porci a tuo riguardo sull'affare del tuo reintegramento in università").

112 Mario Niccoli correspondence, 21 December 1944, Giorgio La Piana Papers, bMS 104, Andover-Harvard Theological Library, Harvard Divinity School ("durante questi anni Buonaiuti non ha certo fatto una buona vita").

${ }^{113}$ Letter from Buonaiuti to Missir, Rome, 21 October 1945, in Buonaiuti, La vita allo sbaraglio, 548.

${ }^{114}$ Giorgio La Piana, "Ernesto Buonaiuti’s Spiritual Vision of Life," Harvard Divinity School Bulletin (1947) 47-67.

${ }^{115}$ L'Editore, "Prefazione" to Ernesto Buonaiuti, La vita dello spirito (Rome: De Carlo, 1948) 5-6 ("la sua conoscenza dei testi religiosi e per la sua amicizia con Buonaiuti").

${ }^{116}$ La Piana, "Ernesto Buonaiuti’s Spiritual Vision," 60-61.

${ }^{117}$ Alberto Pincherle correspondence, 5 January 1947, Giorgio La Piana Papers, bMS 104, Andover-Harvard Theological Library, Harvard Divinity School. La Piana's text was actually published: Giorgio La Piana, "La visione spirituale di Ernesto Buonaiuti," Ricerche Religiose 19 
After Buonaiuti's death, Levi Della Vida also held a heartfelt commemoration ceremony for his friend in the Aula Magna of the Rome Faculty of Letters on 20 June 1946. ${ }^{118}$ Numerous initiatives were also taken by his disciples in memory of their teacher: an Associazione Ernesto Buonaiuti per gli studi storico religiosi (Ernesto Buonaiuti Association for Historical Religious Studies) was founded, to which Levi Della Vida, Donini, Niccoli, Pincherle, Luigi Salvatorelli, Raffaele Pettazzoni and La Piana all belonged. The group took on the task of resuming publication of the journal Ricerche Religiose (which had changed its name to Religio in 1934 and which had been discontinued in February 1944 because of the war) and Religio recommenced publication in March 1947. The aim of the association and of the journal was to "spread scientific knowledge of the history of Christianity" and to "arouse an increasingly keener interest in historical-religious studies."119

La Piana retired a few years after the end of the World War II. In July 1947, he became John Hopkins Morrison Professor of Church History Emeritus. ${ }^{120}$ The historical issue of Modernism remained the focus of his interests. At the end of the 1960s, he set himself the objective of writing a book, which he never completed, on the religious crisis of the early twentieth century. ${ }^{121}$ What is strange, as George Williams $^{122}$ also emphasizes, is that there remain no documents containing his reflections or point of view on Pope John XXIII and the Vatican Council II. This is even more surprising if we consider that the few survivors of the religious crisis at the beginning of the twentieth century, such as Antonino De Stefano and Tommaso Gallarati Scotti, interpreted Modernism as an anticipation of the church of the 1960s. The close relation between the instances of renovation promoted by Modernism and the Vatican II Council would remain a contested scholarly debate. ${ }^{123}$ La Piana died on 4 March 1971. With him died the last witness to the important and troubled movement of religious reawakening, which demanded a new relationship with the modern world.

(1948) 1-14 ("E' veramente una bellissima cosa, viva e calda e piena di comprensione: forse ciò che di meglio si è scritto su di lui: tanto bella che la sto traducendo, per pubblicarne una parte nello speciale di Ricerche religiose").

${ }^{118}$ Giorgio Levi Della Vida, "Ernesto Buonaiuti," Ricerche Religiose 18 (1947) 1-17.

119 "Al lettore," Ricerche Religiose 18 (1947) 1 ("di diffondere la conoscenza scientifica della storia del cristianesimo" e di "suscitare un sempre più vivo interesse per gli studi storico-religiosi").

${ }^{120}$ Williams, "Professor George La Piana (1878-1971). Catholic Modernist at Harvard," 138-39.

${ }^{121}$ Texts conserved at the Andover-Harvard Theological Library, and widely used for writing this article; they are the proofs of a book that La Piana was working on between 1967 and 1969.

122 Williams, "Professor George La Piana (1878-1971)," 139.

${ }^{123}$ Lorenzo Bedeschi, Interpretazione e sviluppo del Modernismo cattolico (Milan: Bompiani, 1975); Daniela Saresella, Dal Concilio alla contestazione (1958-1968) (Brescia: Morcelliana, 2005); Guido Verucci, L'eresia del Novecento. La Chiesa e la repressione del Modernismo in Italia (Turin: Einaudi, 2010). 